\title{
DIE INVLOED VAN STRES OP DIE GEHALTE VAN WERKLEWE AAN 'N TERSIÊRE OPLEIDINGSINSTELLING
}

\section{Rina Buys, Lourie Terblanche}

\section{INLEIDING}

"Sukses" word gemeet aan die effektiewe bydrae wat elkeen maak ter bevordering van die funksionering van sy/haar werk, gesin en die breë gemeenskap (Burud \& Tumulo, 2004:31; Cascio, 2003:31,672).

In die hedendaagse samelewing streef mense toenemend na 'n sinvolle betrekking wat uitdagings en geleenthede bied om uitdrukking aan hul talente te gee. Hoewel daar meer waarde aan 'n gebalanseerde lewe geheg word, waarbinne die loopbaan én die gesin hul regmatige deel kry, slaag werkende mense nie noodwendig in die handhawing van die genoemde balans nie.

Hoewel werkgewers neig om aspekte van gehalte, produktiwiteit, en dienslewering aan te spreek, ignoreer hulle dikwels die impak van stres op die werknemer, terwyl stres ooglopend 'n saak is wat aangespreek behoort te word. Werkgewers huldig dikwels die mening dat werknemers self die balans in hul lewens moet handhaaf (Kenny, 2000:380; Steenkamp \& Van Schoor, 2002:ix) en word die werknemer se reaksie op die voortdurend veranderende werksomgewing (Jansen, 2002:160; Sithole, 2002:21) en gepaardgaande stressore as die bepalende faktore beskou in die bereiking van gesondheid en welstand aldan nie. Van die werknemer word verwag om balans te bewerkstellig tussen die verskillende eise wat aan hom gestel word in die werk-gesin interaksie ten einde te voorkom dat gemelde veranderinge aanleiding gee tot 'n streservaring wat die werknemer se gehalte van werklewe negatief beïnvloed (Barling, 1995:20-21; Claassen, Schepers \& Roodt, 2004:83; Frone, 2003:145; James \& Arroba, 1999:29; Kenny, 2000:384).

In hierdie artikel word 'n literatuuroorsig verskaf en geïntegreer met die navorsingsbevindige soos uit die oorspronklike studie verkry, waarna dit opgevolg word met die aanbevelings en die slotopmerking. Die kwantitatiewe navorsingsbenadering is as aangewese benadering en die aangepaste “ASSET"-posvraelys (Babbie, 2007:298; Cartwright \& Cooper, 2004:120; Neuman, 1997:31) as geskikte data-insamelingsmetode vir die studie geïdentifiseer en aangewend. Die ondersoek is by 'n groot tersiêre opleidingsinstelling in Suid-Afrika, onderneem. Die waarskynlikheidseleksie proporsioneel-gestratifiseerde steekproef (Babbie \& Mouton, 2006:191), is gebruik in die seleksie van respondente vanuit die twee gekose fakulteite ten einde ondersoek in te stel na die aard, omvang en impak van stres op die GWL van werknemers aan die betrokke tersiêre opleidingsinstelling. Die populasie het uit 760 personeel bestaan (593 akademiese personeellede en 167 nie-akademiese personeel). Driehonderd (300) vraelyste is in elk van die twee fakulteite versprei om 'n steekproefgrootte van 600 te verkry. 'n Totaal van 114 (19\%) vraelyste is terug ontvang, wat 81 akademiese personeellede en 33 nieakademiese personeellede vanuit beide fakulteite ingesluit het.

In die artikel fokus die outeurs slegs op drie kernaspekte van die navorsingsbevindinge, naamlik stressimptome, werklading en faktore wat stres by werknemers veroorsaak, wat geïntegreerd met die literatuur aangebied word. Die meerderheid respondente wat aan die studie deelgeneem het, is Afrikaanssprekend (79\%) en word verteenwoordig deur 38 manlike en 76 vroulike respondente. Die ouderdomsverspreiding van die respondente was hoofsaaklik 
in die ouderdomsgroep van 26 tot 55 met 'n laer getal verteenwoordiging onder 25 jaar en bo 56 jaar. Die biografiese inligting van die respondente dui daarop dat daar 'n eweredige verspreiding van deelnemers oor die volle spektrum van ouderdom, geslag, kwalifikasie, posvlak en jare diens aan die tersiêre opleidingsinstelling is.

\section{GEHALTE VAN WERKLEWE}

Die Australian Bureau of Statistics (2001:6) beskou gehalte van lewe as die mens se hele lewenspad, met inagneming van elke lewenssituasie en sosiale konteks wat 'n invloed kan uitoefen op die individu se lewensgehalte of die kohesie van die samelewing. Gehalte van werklewe (GWL) vind dan ook hierin sy inslag op die werkende individu. Die wyse waarop individue in hul werksituasie reageer, hou belangrike gevolge in vir die individu se persoonlike geluk, die organisasie se produktiwiteit en selfs die stabiliteit van 'n samelewing (Burud \& Tumolo, 2004:193; Cascio, 2003:27). As studieveld behels GWL in essensie die intrinsieke menslike aksies en reaksies op faktore by die werk en verwys verder na 'n proses ter verbetering van organisasie-effektiwiteit en verbeterde GWL vir die werknemers.

\section{Die wêreld van werk}

Effektiewe werkverrigting as die individu se voortgesette doel is een van die vernaamste komponente in die bereiking van langtermyn geluk. Die individu se belewenis van sy wêreld van werk is dus belangrik, aangesien die meeste insette in die individu se ervaring van geluk, aldan nie, hoofsaaklik deur hul werksomgewing verkry word. GWL het vir elke individu 'n verskillende betekenis. Elke werknemer se waardes en behoeftes, en die mate waarin die organisasie in die behoeftes voorsien, bepaal of GWL vir die werknemer 'n positiewe werklikheid gemaak word aldan nie.

Die werknemer beskou werksomgewing as die plek waar hy sy identiteit, rol en posisie in die samelewing en onder andere in portuurgroepe ontdek en vestig en 'n mate van ekonomiese onafhanklikheid kan bereik. Claassen et al. (2004:82) stel dit duidelik dat werk verskillende betekenis en waarde vir verskillende persone inhou. Dus, het nie elke werknemer dieselfde verwagting van werk nie en derhalwe word die gehalte van werklewe verskillend ervaar ten spyte van dieselfde werksomgewing waarbinne kollegas hulle bevind.

Werk word as 'n belangrike aspek van die volwassene se lewe beskou, veral vanweë die feit dat werknemers 'n groot gedeelte van hul lewens in die werkplek deurbring. Die literatuur beklemtoon die feit dat werk - weens verskeie redes as belangrike aktiwiteit in die individu se lewe beskou word, waaronder vergoeding, maatskaplike funksionering, persoonlike status en persoonlike intrinsieke waarde. Met 'n betrekking as middel tot die doel, moet daar derhalwe 'n gunstige klimaat geskep word waar die organisasie die werknemer in staat stel om produktief tot die voordeel van die organisasie te handel maar terselfdertyd ook in sy eie behoeftes voldoen.

\section{Die werkgewer as organisasie}

Die totale werksomgewing het aansienlik verander oor die afgelope dekade weens die demokratisering van Suid-Afrika. Universiteite het sedert 1994 in verskeie opsigte verander en was ook onderworpe aan die statutêre vereistes, soortgelyk aan organisasies in die sakesektor en met dieselfde impak op sy werknemers (Jansen, 2002:160; Sithole, 2002:21-31). Die impak hiervan was werksonsekerheid, herstrukturering, transformasie, werkoorlading en gepaardgaande werkstres. Die universiteit as werkgewer, behoort na verwagting dus ook die verantwoordelikheid te dra om 'n werksomgewing te skep wat aan elke werknemer sekuriteit, 
geborgenheid, en werkstevredenheid verseker. Die werkgewer behoort die uitdaging te aanvaar om balans tussen werkstevredenheid en produktiwiteit te handhaaf, ten einde die werknemer se gehalte van werklewe te verhoog.

\section{Veranderlikes van gehalte van werklewe}

Ten spyte van die feit dat die werknemer eie belange vooropstel en die werkgewer produktiwiteit en wins najaag, impakteer die resultate hiervan op meer terreine van die individu se lewe as bloot net die werkplek. Voortspruitende hieruit, het die literatuur bevestig dat die gesins- en werksomgewing op mekaar impakteer as gevolg van die voortdurend veranderende werksomgewing en gesinsisteme (Barling, 1995:19-20). Verder dra die onderliggende invloede by tot die werknemer se gesindheid en motivering wat bepalend is vir die werknemer se optrede en gedrag in die werksituasie. Die hantering van die verskillende rolle deur die individu, vorm die kern van die veranderlikes in die ondersoek na GWL en die invloed van stres op die individu.

\section{Komponente van gehalte van werklewe}

Meerderheid organisasies het winsgewendheid as doelwit. Ten einde winsgewend te wees, word staat gemaak op die doeltreffendheid van die organisasie se werknemers. Werknemers se primêre behoefte is om te kan werk binne 'n klimaat waar GWL 'n positiewe ervaring is (Claassen et al., 2004:83). Met die voorafgaande as vertrekpunt, word die mening gehuldig dat die dimensies van GWL, onder andere die volgende behels: veiligheid, gesondheid, goeie werksomgewing, regverdige beloning, werksekuriteit en loopbaangeleenthede wat bevordering en erkenning insluit.

Die komponente van GWL (met inbegrip van prestasiebestuur, produktiwiteit, werkstevredenheid, konflik in die werkplek, organisasiekultuur en organisasieklimaat) dui aan dat die individu se sukses in die hantering van werkseise, 'n bepalende invloed op sy produktiwiteit en werksprestasie het. In teenstelling met die algemene opvatting dat 'n gelukkige en tevrede werknemer beter presteer, het Vroom (1964:101) reeds in die vroeë sestiger jare bevind dat 'n tevrede werknemer nie noodwendig goeie werksprestasie lewer nie. Ten spyte van Vroom se siening, merk Requena (2003:331-360) dan ook tereg op dat werkstevredenheid as 'n belangrike indikator vir GWL, beskou kan word.

\section{STRES IN DIE WERKPLEK}

Stres in die werkplek vorm 'n belangrike en onvermydelike deel van die werknemer se lewe met 'n bepalende invloed op die werknemer se gehalte van werklewe. Navorsing het reeds bewys dat ten spyte van die feit dat werkverrigting as die mees waardevolle bron van tevredenheid beskou kan word, werk terselfdertyd ook die bron is wat die mééste stres veroorsaak.

Die werksomgewing het oor die afgelope dekade aansienlik verander, met verwysing na die demokratisering van Suid-Afrika in 1994 waartydens druk op die totale samelewing toegepas is om verskeie ingrypende veranderinge teweeg te bring en te bestuur. Universiteite en ander opleidingsinstellings is ook deur verskeie makro-veranderinge in die onderwysomgewing beïnvloed en moes gevolglik ná 1994 verskeie aanpassings maak. Die impak van hierdie veranderinge in die werkplek, het gelei tot werksonsekerheid, herstrukturering, transformasie, werkoorlading en gepaardgaande werkstres.

Verespej (2000:5) wys daarop dat “...there is a commonality with the kinds of problems at work that cause stress and the kind of problems that employees are probably dealing with in their lives". Daar kan dus aangevoer word dat 'n negatiewe werksituasie 'n kritieke situasie vir 
die individu is, wat tot werkstres kan lei. Cartwright en Cooper (1997:5) definieer stres dan ook as "... any force that puts a psychological or physical function beyond its range of stability producing a strain within the individual". Uit die voorafgaande is dit dus duidelik dat daar 'n verband tussen stres en 'n negatiewe werksomgewing bestaan.

Van Klaveren en Tijdens (2007:6) beskryf werkstres as “...a pattern of reactions occurring when workers are confronted with demands concerning their work that are not matched to their competencies and resources, and with which they have problems to cope". Wanneer 'n werknemer bewus word van die wanbalans tussen werkseise en sy bekwaamheid en hulpbronne, ontwikkel die werknemer emosionele-, kognitiewe-, gedrags-, en sielkundige reaksies. Elke individu reageer dus, binne sy unieke situasie en individuele eienskappe, verskillend op stressore en lewer derhalwe verskillende uitkomste.

Studies wat in Kanada, die Verenigde State van Amerika, die Verenigde Koninkryk, die Europese Unie, Australië en Brasilië uitgevoer is, het aangedui dat stres die enkele belangrikste oorsaak van psigiese- en fisiologiese siektes is (Tangri, 2003:13-14). Hierdie studies het ook uitgewys dat stres verantwoordelik is vir 19\% van afwesighede, $40 \%$ van die personeelomset, $30 \%$ van korttermyn mediese ongeskiktheid, $10 \%$ van mediese- en farmaseutiese kostes, en $60 \%$ van die koste van werksongelukke. Studieresultate wat die Institute of Risk Management of South Africa (IRMSA) in Oktober 2005 vrygestel het, stem ooreen met dié van voorgemelde internasionale studieresultate. IRMSA (2005:2) het aangedui dat werknemer-afwesigheid hoofsaaklik toe te skryf is aan siekte $(61 \%)$ en familie/persoonlike redes $(26 \%)$. By nadere ondersoek is verskeie oorsake van stres aangedui, waarvan werkoorlading die grootste faktor (37\%) blyk te wees. Sowel genoemde navorsing (63\%) as die resultate van 'n studie wat ook by 'n Suid-Afrikaanse universiteit onderneem is (Mapesela, 2004:272), ondersteun die feit dat werkoorlading die primêre oorsaak van verhoogde stresvlakke is.

Nieteenstaande die voorafgaande, word stres steeds nie deur organisasies as 'n risiko geag nie, maar navorsing deur IRMSA (2005:15) dui op 'n ooreenstemming tussen stres en 'n verswakte immuunsisteem wat aanleiding gee tot verskeie siektetoestande soos hoofpyne en verkoues. Hierdie navorsing bevestig voorafgaande waar aangedui is dat hoofpyne $(17 \%)$ die mees algemene, hoewel geringe fisiese simptoom van stres blyk te wees en veral voorkom by ondersteuningspersoneel. Gemelde siektetoestande lei tot afwesighede wat die organisasie negatief kan beïnvloed.

\section{Perspektiewe van stres}

Stres fokus op "equifinality", "eustress", "distress", persoon-omgewing aanpasbaarheid, lokus van kontrole, asook Karasek se "demand-control"-model (Davies \& Cicchetti, 2004:477; Edward, Caplan \& Van Harrison, 2000:28; Grimshaw, 1999:35; Lu, Wu \& Cooper, 1999:1; McGowan, Gardner \& Fletcher, 2006:2-3). Die siening volgens gemelde perspektiewe is noodsaaklik ten einde die interaksie van werk stressore en stres, asook die impak daarvan op die werknemer, te begryp.

Die beginsel van "equifinality" word gebruik om aan te dui dat daar meer as een aanleidende of veroorsakende faktor is wat vir 'n gegewe uitkoms oorweeg moet word. Davies en Cicchetti (2004:477) verklaar "equifinality" as 'n ontwikkelings-psigopatologiese beginsel wat aandui dat gedrag of versteuring verskeie oorsake kan hê. In hierdie konteks kan verwys word na gesins- en kontekstuele faktore wat daartoe aanleiding gee dat verskillende individue verskillende rolle aanneem in die aanwesigheid van 'n versteuring soos stres. Gesinsfaktore verwys na faktore binne gesinsverband wat as stressore kan dien, onder andere die onderlinge 
verhoudinge binne die gesin. Kontekstuele faktore verwys na die konteks waarbinne die individu sy werk moet verrig. In hierdie verband verwys kontekstuele faktore na stressore wat die organisasieklimaat (algehele gemoedstoestand) kan beïnvloed.

Die term "eustress" was deur Selye gebruik om die positiewe aspekte van stres aan te dui. Nelson en Simmons (2003:103) verwys na hoop, sinvolheid en die positiewe effek as prominente aanduidings van "eustress". "Eustress" word ook met taakbetrokkenheid verbind, waar die werknemer hom beywer om "...enthusiastically involved in and pleasurably occupied by the demands of the work at hand", te wees (Nelson \& Simmons, 2003:103). Hierdie toestand van vervulling kan daartoe lei dat die werknemer so aktief in sy werk betrokke raak dat niks anders vir hom saak maak nie. "Distress" verwys na die individu se negatiewe sielkundige respons op 'n stressor (McGowan et al., 2006:3).

Persoon-omgewing aanpasbaarheid (P-O model) word deur Edward et al. (2000:28) omskryf as stres wat sy oorsprong het in die nie-aanpasbaarheid van die individu met die werk en die werksomgewing. In hierdie konteks verwys die persoon-omgewing aanpasbaarheid na die effek en impak van die individu se persoonlike- en omgewingsveranderlikes op sy gehalte van werklewe. Die afleiding kan dus gemaak word dat 'n positiewe effek van P-O aanpasbaarheid tot 'n positiewe belewenis van gehalte van werklewe en verhoogde produktiwiteit bydra. Die negatiewe impak van P-O aanpasbaarheid, kan aanleiding gee tot die werknemer se belewenis van stres binne die werksituasie en gevolglike negatiewe belewenis van gehalte van werklewe.

Lokus van kontrole volgens Phillips (2005:23), is gebaseer op die veronderstelling dat die verwagte uitkoms van 'n gebeurlikheid deur die individu, eksterne faktore en ander persone, beïnvloed kan word. Die beïnvloeding van 'n uitkoms deur die individu, verwys na interne lokus van kontrole en die invloed van eksterne faktore en persone, dui op die eksterne lokus van kontrole. Vroeëre navorsing het getoon dat die interne lokus van kontrole verbind word met die verlaagde persepsie van werkstres en selfs algemene lewensstres (Lu et al., 1999:3). Binne die konteks van werk en werkstres, verwys lokus van kontrole na die mate waarin individue glo dat hulle beheer oor 'n spesifieke aspek van hul werk, kan uitoefen. Paulse (2005:38) meld in hierdie verband dat lokus van kontrole aangewend word om onder andere die werkstempo, prosedures, en werkskedules, asook besluitneming, te beïnvloed.

Werkgewers is deurlopend besig om wyses te ondersoek waarmee hul werknemergesondheid, werkstevredenheid, en produktiwiteit kan bevorder. Die American Psychological Association (APA), in hul inligtingstuk "Occupational Stress and Employee Control" (2003), maak daarvan melding dat indien die werknemer meer beheer oor sy werk verkry, hy laer stresvlakke presenteer en dat motivering en groei sodoende bevorder word. Voortspruitend uit hierdie vermeerderde beheer en laer stresvlakke, het Karasek in 1979 die eise-kontrole model en vraelys ontwikkel. Die vraelys fokus op die aanname van twee hipoteses, naamlik (1) dat die kombinasie van hoë werkseise en lae werkkontrole aanleiding gee tot sielkundige- en fisiese spanning en (2) dat 'n werk, waar werkseise en kontrole in balans is, daartoe aanleiding gee dat die werknemers 'n hoë mate van welstand, ontwikkeling en groei ervaar (Grimshaw, 1999:35). Karasek fokus op die identifisering van bepaalde werkstressore wat verband hou met die beheer van die werknemer in sy werk en werksomgewing. Vir die werkgewer sal dit toepaslik wees om kennis te dra van die belangrikheid van die werknemer se interne lokus van kontrole, asook om die Karasek-vraelys in die assessering van werknemers in hul werk en werksomgewing te benut. 
12 maande ervaar het. Stres kan die gevolg wees van slegs een of 'n kombinasie van die volgende tipes stres: huislike-, finansiële-, gesondheids-, of werksomstandighede. Die eise van die werksomgewing speel 'n vername rol in die belewenis van stres deur werknemers. Die kompleksiteit van die impak van stres op die werknemer én die organisasie, is gesetel in die feit dat daar ' $n$ verskeidenheid oorsake bestaan en dat elke individu uniek op die bepaalde stressore reageer. Indien die werkstressore dus nie beperk en werkstres nie beheer word nie, kan dit ernstige nagevolge vir sowel die werknemer as die organisasie inhou.

Navorsers (Clarke \& Cooper, 2004:127; Leka, Griffiths \& Cox, 2003:6-7) het bevind dat die vernaamste oorsake van stres, werksverwante faktore is. Veroorsakende faktore van werkstres sluit werkonsekerheid, werkoorlading, gebrek aan werksekuriteit, rasionalisasie, tegnologiese ontwikkeling, rolkonflik en -verwarring, organisasieklimaat en -kultuur, taakverskeidenheid, gebruik van vaardighede, gebrekkige opleiding, beperkte loopbaanvooruitsigte en beperking op bevorderingsmoontlikhede, gebrekkige outonomie in die werksituasie, swak werksverhoudinge, onvoldoende beloning en beperkte voordele in. Stresveroorsakende faktore buite werkverband sluit in die handhawing van balans tussen die werk en die gesin, onbevredigende gesondheid en gebrekkige sekuriteit in.

Stressituasies aan universiteite ontstaan as gevolg van werksverhoudinge, tyd- en hulpbronbeperkings, werkoorlading en 'n oorgereguleerde werksomgewing (Anderson, Guido-DiBritto \& Morrell, 2000:104-105). Die werknemers se streservaring in die werkplek word oor die algemeen vererger deur die kombinasie van administratiewe eise, toename in studentegetalle en die bereiking van spertye. Hierdie sameloop van verskeie werkseise gee verder daartoe aanleiding dat werknemers buite normale werksure moet werk. Die verlengde werksure veroorsaak stres aangesien die inmenging van die werk met die gesinslewe, gesinsverhoudinge negatief beïnvloed.

Verdere faktore wat bydra tot stres by werknemers aan universiteite, sluit in hoofde se bestuurstyle, misdaad, en politieke veranderinge (Paulse, 2005:28). Navorsing wys daarop dat werkstoestande, werksure, werkoorlading, reis en tegnologiese ontwikkeling van die vernaamste stressore vir werknemers aan universiteite is (Cartwright \& Cooper, 1997:16). Vanuit voormelde, word die mening gehuldig dat dit juis die organisasie (universiteit) en bestuurders se ekonomiese ingesteldheid is wat veroorsaak dat die menslike faktor en hul behoeftes in operasionele beplanning agterweë gelaat word.

Werkoorlading gee aanleiding tot ongereelde en langer werksure. Cartwright en Cooper (1997:16) onderskei tussen kwantitatiewe en kwalitatiewe oorlading. Kwantitatiewe oorlading verwys na die hoeveelheid werk wat 'n bepaalde werknemer binne die gegewe werksure moet afhandel. Daar kan dus aangevoer word dat werkoorlading by 'n werknemer aanwesig is indien die werknemer nie sy werk binne die gegewe tydperk kan afhandel nie, ten spyte daarvan dat werknemer produktiwiteit bewys kan word. Deur die evaluering van werklading as veranderlike in hierdie navorsing, is bepaal wat die respondente as stresveroorsakende faktore beskou en wat hul ervaring daarvan is. Ten spyte daarvan dat werknemers geen vergoeding vir oortydwerk ontvang nie, het die meeste respondente $(66 \%)$ se werklading van hulle vereis om oortyd te werk en kon hulle derhalwe nie normale kantoorure handhaaf nie. Oor die afgelope dekade het die effek van die wêreldwye ekonomie, die werksklimaat binne organisasies drasties beïnvloed. Dollard (2003:1) meld in hierdie verband dat die verhoogde druk en pas waarteen werk voltooi moet word ook 'n invloed op werknemers het. 
Kwalitatiewe oorlading verwys, volgens Cartwright en Cooper (1997:16), na werk wat te moeilik vir die individu is om te hanteer én wat langer werksure, ten einde die taak af te handel, verg. Vanuit voormelde blyk dit dus dat gelyke indiensneming en die rasionaliseringsbeleid wat geïmplementeer word, aanleiding kan gee tot kwalitatiewe oorlading. Kwalitatiewe oorlading ontstaan dus daar waar korrek gekwalifiseerde personeel aangestel word en hulle weens hul beperkte ervaring, aan 'n omgewing blootgestel word waarin hulle nie die posvereistes kan nakom nie. Die verhoging in werklading en gepaaardgaande blootstelling aan en uitvoering van "vreemde" take en opdragte is die direkte gevolg van die verandering in werksomstandighede, met spesifieke verwysing na die herstrukturering binne die tersiêre instelling, asook die implementering van nuwe inisiatiewe wat deur wetgewing voorgehou word.

Green en Hatch (2002:298) beklemtoon die impak wat herstrukturering op GWL het in hul ondersoek na die veranderende werksomgewing. Veranderinge in die werksomgewing word hoofsaaklik teweeg gebring deur verandering weens politieke vereistes en verandering weens tegnologiese vooruitgang. Die negatiewe impak van die veranderde werksomstandighede, dra by tot die werknemers se streservaring en negatiewe beskouing van loopbaanvooruitsigte en bevorderingsmoontlikhede (werk meng in met persoonlike lewe). Metcalf, Rolfe, Stevens en Weale (2005:31-32) meld dat toename in werklading een van die grootste bronne van stres vir akademici is. Hulle dui ook daarop dat die tydperk 1998 tot 2004 tekenend van geweldige toename in werklading in die akademie was wat kon bydra tot verhoogde stresvlakke en vermindering in werksbevrediging.

Organisasiekultuur kan in sommige organisasies aanleiding gee tot die individu se streservaring. Organisasiekultuur word bepaal deur die spesifieke struktuur, leierskap en organisasieklimaat wat deur 'n bepaalde organisasie aangeneem word (Cartwright \& Cooper, 1997:26). Sielkundige spanning word dikwels volgens Paulse (2005:28) deur die historiese organisasiekultuur en bestuurstyle binne 'n organisasie veroorsaak.

Rolkonflik, rolonduidelikheid en -verwarring is aspekte wat dikwels werksverhoudinge vertroebel en stres by die werknemer veroorsaak (Quick \& Tetrick, 2003:335). Werknemers ervaar rolkonflik wanneer hul gekonfronteer word met afwisselende verwagtings van hul toesighouers en bestuurders. Martel (2005:10) wys daarop dat rolkonflik ontstaan wanneer die organisasie se waardes en doelwitte met dié van die werknemer bots. Verder, kan rolkonflik ontstaan wanneer die hulpbronne om die taak na behore uit te voer, ontbreek. Rolonduidelikheid en -verwarring ontstaan dus wanneer die werknemer nie weet wat van hom verwag word nie. In hierdie geval kan die werknemer nie vooruitgang in sy loopbaan maak nie, aangesien hy onseker is oor die verwagte doelwitte en uitkomste.

Elke werknemer het 'n bepaalde verantwoordelikheid wat gekoppel word aan die posvlak binne die organisasie se hiërargie en wissel derhalwe in intensiteit. Cartwright en Cooper (1997:18) meld dat hierdie verantwoordelikhede stres tot gevolg kan hê as gevolg van die versekering van werksekuriteit vir werknemers en begrotingsbeheer ten einde die maksimum produksie teen die laagste koste te bereik. Die responsresultate van die navorsing dui daarop dat die meeste respondente $68(60 \%)$ van mening is dat hul negatiewe belewenis en interpretasie van hul werksomstandighede en gepaardgaande teenstrydige eise en onduidelike posbeskrywings daartoe aanleiding gee dat hulle voel dat hul werk nie na waarde geag word nie. Genoemde belewenis dui daarop dat gebrekkige erkenning ervaar word. Hierdie responsresultate bevestig Hay en Fourie (2002:130), asook Coetzee en Rothman (2005:30) se bevindinge dat voormelde omstandighede daartoe bydra dat werknemers die siening handhaaf dat hulle nie na waarde geag word nie, wat kan lei tot 'n negatiewe belewenis van die gehalte van werklewe. 
Met die voorafgaande as vertrekpunt, word die mening gehuldig dat die impak van stressore op die werknemer beperk kan word. Dit kan bereik word deur aanpassings te implementeer ten einde werkseise te beperk deur onder andere die uitbreiding van personeel, die aanstelling van meer kundige- en bekwame persaoneel en ondersteunende leierskap.

\section{Stressore intrinsiek tot akademici}

Stressore inherent tot die werk, met spesifieke verwysing na akademici, kan die bereiking van spertye, werkoorlading en lang werksure insluit. Hierdie stressore het hul oorsprong in die verhoging van studentegetalle en die gevolglike swakker student-dosent ratio. Voormelde word ondersteun deur Gillespie, Walsh, Winefield, Dua en Stough (2001:54) asook Winefield (2003:241) wat aandui dat universiteite, onder andere in Australië, 'n toename in studentegetalle tot so hoog as $50 \%$ toon.

Indien in ag geneem word dat die toename in studentegetalle verantwoordelik is vir verhoogde werklading en gevolglike langer en meer klasure, word dit duidelik dat beter beheer oor studentegetalle 'n positiewe effek op die werknemers se streservaring sal hê. Akademici word egter ook blootgestel aan teistering, en navorsingsbevindinge het aan die lig gebring dat meer as die helfte van akademici (51\%) die teistering deur studente as stresvol beleef. Binne voormelde konteks aan 'n opvoedkundige instelling, verwys teistering dus na studente-gedrag wat akademici fisies of emosioneel bedreig. Segumpan en Bahari (2006:174) bevestig hierdie bevindinge en meld dat studente wangedrag en in besonder afknouery ("bullying"), deur werknemers as ' $n$ bron van stres beskou word. Akademici se ervaring van studente-teistering kan moontlik 'n gevolg van die hoë studentegetalle, ontoereikende fasiliteite en toerusting wees.

Die stressore met betrekking tot organisasiestruktuur en -klimaat sluit verandering en die bestuur van sodanige verandering, uitsluiting in bestuur- en personeelbesluite en veelheid van werkseise in. Die akademici word in hierdie verband direk geraak as gevolg van die samesmelting van tersiêre opleidingsinstellings. Die gevolg van die samesmelting is dat doseerpersoneel meer klasse, en veral veeltalige klasse moet aanbied. Akademici word dus nou gekonfronteer met ras, taal en kultuur diversiteit van studente en kollegas wat volgens Ullyat (2003:85) asook Coetzee en Rothman (2005:47) bydra tot werknemers se stresbelewenis as gevolg van die bedreiging wat deur die veranderinge veroorsaak word. Verskeie aspekte van diversiteit, wat ras, taal en kultuur insluit, gee daartoe aanleiding dat konflik tussen werknemers ontstaan. Die wyse en prosesse waarmee konfliksituasies afgehandel word, word deur werknemers as stresvol beleef. Die diversiteitsgedrewe konflik en gepaardgaande konflikhantering word deur die meeste werknemers as stresvol beleef. Die verlangsaming of spoedige afhandeling van konfliksituasies is aanduidend van die versigtigheid en vrees wat deur werknemers tydens konfliksituasies ervaar word. Galinsky, Bond en Friedman (1996:133) verwys na hul navorsingsresultate wat daarop dui dat werknemers "...who had more supportive supervisors, had more supportive workplace cultures...reported somewhat less conflict, less stress, and better coping...". 'n Belangrike aspek in die afhandeling van konfliksituasies is dus dat albei partye die proses as konstruktief en positief moet beleef.

Verdere organisasie-stressore spruit voort uit pogings - dikwels onsuksesvol - tot die verkryging van eksterne befondsing vir opleiding, navorsing en projekte. Die afgelope dekade is tendense van jaarlikse vermindering van staatsubsidies aan universiteite merkbaar aanwesig. Winefield (2003:241) wys daarop dat die vermindering van subsidies ook die universiteite in die Verenigde Koninkryk en Australië beïnvloed het. Die aanbied van nuwe kursusse word ook 
in hierdie navorsing deur die meeste akademici (83\%) as stresvol beleef. Bydraend tot die streservaring is die feit dat van akademici verwag word om hoogstaande gehalte onderrig te lewer ten spyte van beperking op fondse, hulpbronne en ondersteuning.

\section{Gevolge van stres op die werknemer}

Stres is die gevolg van langdurige blootstelling aan omstandighede waar die individu ervaar dat hy nie die hulpbronne of vermoë het om die situasie die hoof te bied nie. Daar bestaan egter 'n verband tussen die werknemer se hantering van die stressituasie en die gevolge van stres, wat vanweë die omvang en intensiteit van stres aanleiding gee tot die aanwesigheid van stressimptome (Putt, 2006:7). In hierdie navorsing is die teenwoordigheid van bepaalde stressimptome dan ook gemeet in terme van die respondente se ervaring van bepaalde stressimptome en die afwesigheid van werk as gevolg van stresverwante siektetoestande.

Die effek van werkstres sal manifesteer in een of meer van sielkundige-, fisiologiese- en gedragsreaksies. Fisiologiese gevolge vir die individu kan hoofpyn, hoë bloeddruk, slapeloosheid en verskeie hartverwante siektes insluit. Clarke en Cooper (2000:174) merk tereg op dat daar genoegsame bewyse bestaan wat werkstres met "serious psychiatric harm and physical disease, such as coronary heart disease" verbind. Die mees algemene simptome hiervan is borspyn, hoofpyn, vlak en vinnige asemhaling, sweet, lusteloosheid, en konstante moegheid. In hierdie verband ervaar akademici (64\%) en administratiewe personeel (69\%) dikwels angstigheid, tekenend van werknemers wat hulself in 'n stresvolle werksomgewing bevind. Hierdie resultaat dui daarop dat akademici en administratiewe personeel aan meer intense stres blootgestel word, veral wanneer beskou word teen die agtergrond van die hoë voorkoms van emosionele- en geestesongesteldhede.

Die individu kan ook sielkundige gevolge van stres beleef (Miller \& Smith, 2004:1). Sielkundige gevolge sluit bekommernis en angstigheid, verlaging in werkstevredenheid, depressie, 'n gevoel van waardeloosheid, wisselende gemoedstoestande (bv. geïrriteerd en beperkte humorsin), frustrasie, moegheid, verswakkende verhoudinge met kollegas, 'n verswakking in geheue en konsentrasie-vermoë, swak besluitneming en beplanning en uiteindelik werknemer uitbranding, in (Cranwell-Ward \& Abbey, 2005:186-187). Angstigheid word egter deur Schafer (2000:125-126) beskou as dié mees algemene emosionele reaksie op werkstres. Tydens 'n vergelyking in hierdie navorsing tussen manlike (42\%) en vroulike (69\%) werknemers, is dit duidelik dat die voorkoms van angstigheid en depressie by vroulike werknemers hoër is as by manlike werknemers. Cranwell-Ward en Abbey (2005:186-187), asook Schafer (2000:125-126) bevestig voorafgaande met hul siening dat angstigheid as dié mees algemene emosionele reaksie op werkstres, beskou kan word. Die hoër voorkoms van angstigheid en/of depressie by vroulike werknemers kan moontlik toegeskryf word aan sosiale rol-oorlading aangesien meeste werkende vroue steeds die "tradisionele" verantwoordelikhede van eggenote en moeder in die huishouding moet vervul.

Die resultaat van 'n vergelyking tussen akademici, administratiewe- en ondersteuningspersoneel het dan ook aangedui dat akademici die hoogste voorkoms van bepaalde stressimptome het (Figuur 3). Die mees prominente stressimptome sluit irritasie, frustrasie en óór-moegheid in. Vanuit voormelde resultaat kan afgelei word dat akademici in vergelyking met administratiewe personeel, aan meer intense stressituasies onderworpe is.

Die fisiologiese- en sielkundige gevolge van stres sal noodwendig 'n invloed op die individu se gedrag uitoefen. Die gedragsimptome van stres het betrekking op die individu se funksionering, wat ook 'n invloed op sy produktiwiteit en effektiwiteit in die werkplek uitoefen (Brun \& 
Die werknemer wat stres ervaar wat tot afwesigheid van werk aanleiding gee, dra by tot die verlies aan produktiwiteit en hou potensiële finansiële implikasies vir die organisasie in. Die impak van stres op produktiwiteit binne universiteite is dus gesetel in die beperkende invloed op die primêre taak, naamlik die aanbied van gehalte onderrig en navorsing. Verlies aan produktiwiteit verswak die onderwys-sektor en ondermyn die vermoë van die universiteit om noodsaaklike onderrig verrig (Meyer, 2007:7). Beperking op die werknemer se optimale produktiwiteit en afwesigheid as gevolg van stresverwante siektetoestande, stel dus 'n beperking op die verskaffing van gehalte onderrig. Daar kan dus gekonstateer word dat afwesigheid van werknemers daartoe aanleiding gee dat werkoorlading plaasvind, aangesien die onderrigproses moet voortgaan en daar vir die afwesige werknemer ingestaan moet word. Gratton (2003:5) se uitspraak dat produktiwiteit verbeter kan word indien die organisasie sy benadering met betrekking tot gehalte van werklewe verbeter, word dan ook ondersteun.

\section{Invloed van stres op die gehalte van werklewe van werknemers}

Volgens die World Health Organisation (WHO, 1986) word gehalte van werklewe bepaal volgens die mate waartoe die werksdruk op die werknemer in gesonde verhouding tot sy vaardighede en hulpbronne staan, gemeet aan die mate van beheer wat werknemers oor hul werk het en die ondersteuning wat hulle verkry van die persone wat vir hulle belangrik is.

Gehalte van werklewe verwys nie na die aanwesigheid van die negatiewe nie, maar na “...a positive state of complete physical, mental and social well-being... not only the absence of harmful conditions but an abundance of health promoting ones" (Leka et al., 2003:4). Elke werknemer se persoonlike hantering van stres bepaal die effek wat werkstres op hom sal uitoefen. Die uitwerking van stres op die individu word bepaal deur individuele verskille in mense, onder andere hul persepsie en uitkyk op die lewe, werkservaring, sosiale- en maatskaplike ondersteuningstelsels, vertroue in lokus van kontrole en vyandigheid.

\section{Invloed van die werknemer se gehalte van werklewe op die organisasie}

Oor die afgelope dekade het die effek van die wêreldwye ekonomie, die organisasieklimaat binne organisasies drasties beïnvloed. Beale (2003) wys daarop dat die makro-omgewing elke organisasie omring en beïnvloed en dat die makro-omgewing sosiale-, politiese-, ekonomiese-, en tegnologiese faktore insluit; asook dat "...the significant feature of the macro environment is that it is changing constantly". Dit is duidelik dat werkstres deur die makro-omgewingsfaktore beïnvloed word, alhoewel baie van die invloede nie deur die werknemer beheer kan wordnie. Volgens Beale (2003) behels sodanige onbeheerbare interne faktore onder andere bestuurstyle, gebrekkige werksekuriteit, lang werksure en algemene werksomgewingsveranderinge, wat die werknemer beïnvloed en op een of ander wyse stres by die werknemer teweegbring. Daar kan dus aangevoer word dat alle faktore wat 'n impak op die werknemer se stres het, deur bestuur erken en aangespreek behoort te word.

Voorts kan organisasie-regulasies en selfs nasionale wetgewing 'n invloed op die verandering van die werksomstandighede uitoefen. Organisasie-uitkomste word bepaal deur die spesifieke insette tydens verandering in die werksomstandighede en veranderingsbestuur deur die organisasie. Die organisasie se goeie bestuursbeginsels kan 'n bydrae lewer tot positiewe hantering van die potensiële verandering in werksomstandighede en sodoende die effek van die verandering op die werknemer verlig.

\section{Rol van die werkgewer in streshantering}

Die werksomgewing verander voortdurend waardeur werknemers deurlopend onder druk geplaas word met gevolglike hoë stresvlakke. Die uitdaging wat organisasies in die gesig staar, 
is om te verseker dat werknemers GWL ervaar deur middel van die handhawing van gunstige produktiwiteitsvlakke, ten spyte van 'n veranderende werksomgewing. Basson (1992:23), asook Calitz en Weyers (1998:37) meld in hierdie verband dat 'n gebalanseerde leefstylbenadering belangrik is in die opvoeding van individue in die hantering van stres, veral aangesien die suksesvolle bemeestering van belangrike lewensvaardighede bydra tot 'n positiewe gehalte van werklewe. Die bemeestering van enkele lewensvaardighede dien as verdere aansporing vir die individu om voortdurend na sukses en groei te streef.

Die National Institute of Occupational Safety and Health (Cummings, 2000:58) huldig die mening dat dit organisasies se verantwoordelikheid is om te voorkom dat stressore in die werksomgewing gevestig word. Organisasies het in hul hantering van die stresproses (stres met gepaardgaande werkstressore), afgewyk van die proaktiewe benadering waartydens die oorsake of veroorsakende faktore van stres aangespreek word.

Atkinson (2000) verwys hier na die aanmoediging van werknemers om 'n weerstand teen stres te ontwikkel en hul te bemagtig om meer immuun teen stres te wees en merk tereg op "... to be more resilient to situations that could result in stress". Die individu se benutting van sekere vaardighede binne die gegewe situasie kan aanleiding gee tot suksesvolle stresvoorkoming. Die teendeel is ook waar, dat indien die individu nie oor vaardighede beskik om homself binne 'n gegewe situasie te handhaaf nie, sodanige onvermoë tot 'n negatiewe streservaring vir die betrokke individu aanleiding kan gee.

\section{Meting van stres}

Werkgewers raak toenemend bewus van die belangrikheid van risiko-assessering, met verwysing na veral stres in die werkplek. Clarke en Cooper (2004:174) verwys na die belangrikheid van risiko-assesserings, waaronder stresmetings, met die doel “...to take adequate measures to control that risk - both to avoid business loss and to ensure a healthy workforce". Die primêre doel van stresmeting is dus om te bepaal in watter mate bestaande of beplande voorsorgmaatreëls doeltreffend is en of daar enige verbeterings aangebring behoort te word, ten einde die behoeftes van beide die werknemers en die organisasie aan te spreek en sodoende ' $n$ bydrae te lewer. Cartwright en Cooper (2004:120) het ' $n$ instrument vir die uitvoer van stresrisiko-evaluering ontwikkel. Die instrument, "A shortened stress evaluation tool" (ASSET) is ontwikkel met die oog daarop om organisasies in staat te stel om self die stresklimaat binne hul organisasie te bepaal. "ASSET" fokus op die breë organisasie-opset deur te bepaal wat die werknemer se persepsie van sy werk is, die gesindheid teenoor sy organisasie en die individu se gesondheidsvlak.

\section{Verband tussen werk, gesin en gesondheid}

In die bestudering van welstand in die werkplek, was dit deurgaans beklemtoon dat welstand nie slegs ' $n$ kortstondige, eenmalige ervaring behels nie, maar 'n volgehoue en deurlopende integrasieproses is wat optimale gesondheid en welstand vir die werknemer, die organisasie en die gemeenskap ten doel het. 'n Mens se gesondheid en welstand word dan ook grootliks bepaal deur lewenstyl en lewensomstandighede wat voortdurend verander en waarby die individu moet aanpas. Hierdie veranderinge beïnvloed die verskillende sisteme waarmee die individu, met die omgewing waarin hy verkeer, in interaksie is en kan ook aanleiding gee tot 'n streservaring wat die werknemer se gehalte van lewe en werklewe negatief kan beïnvloed. In aansluiting hiermee, is dit ook duidelik dat die werknemer se reaksie op die voortdurend veranderende werksomgewing en gepaardgaande stressore as dié deurslaggewende faktore beskou word in die bereiking van gesondheid en welstand. Die werknemer, met ondersteuning 
van die werkgewer, is derhalwe verantwoordelik om balans tussen die onderskeie sisteme waarbinne hy funksioneer, te bewerkstellig.

Werk en die werksomgewing is op sigself 'n streservaring vir die werknemer. Ten spyte van die werknemer se bestaande kapasiteit om stres te hanteer (Bishop, 1998:183), het die blootstelling aan stressore 'n direkte effek op sy algehele gesondheid (Heaney, 2003:306). Die intensiteit van die blootstelling aan stressore, tesame met die werknemer se respons op die stressore, kan dus negatiewe fisiese-, sielkundige- en/of gedragsgevolge inhou. Levi (2000:235) meld dat gesondheidsrisiko's en die suksesvolle bestuur daarvan, die grootste enkele bepalende faktor is vir die moontlikheid om 'n gesonde lewe te lei. Stres word deur Romas en Sharma (2000:9) beskou as 'n gesondheidsrisiko wat direk of indirek geassosieer kan word met 'n verskeidenheid van siektes, onder andere hipertensie, koronêre hartsiekte, beroerte, hoofpyne en brongiale asma. Dit is dus belangrik om nie die ernstige gevolge van stres te ontken nie. Die ontkenning van stres en die gevolge daarvan kan daartoe aanleiding gee dat die werknemer nie ernstig is om basiese stresbeheer aan te leer en toe te pas nie.

Vanuit voormelde kan die afleiding gemaak word dat welstand 'n deurlopende en dinamiese proses is, aangesien dit ' $n$ wisselwerking met die individu se veelheid van rolle insluit. Die veelheid van rolle impliseer dat die individu met ander mense in interaksie is en kan dus deur sy gedrag en optrede, die welstand van ander persone beïnvloed.

\section{Welstandstrategieë vir gesondheidsbevordering}

Die werkplek, die organisasie en stres wat deur werk veroorsaak word, word volgens Csiernik (2005:37) as van dié vernaamste oorsake van siekte by werknemers en verlaagde organisasieeffektiwiteit beskou. Organisasies en werkgewers word toenemend onder druk geplaas deur bepaalde maatskaplike invloede om voortdurend die werkplek en werklewe van werknemers te verbeter. Lae moraal, swak werksbywoning, verlaagde produktiwiteit en hoë werknemeromsette veroorsaak 'n rimpel effek met verreikende gevolge vir sowel die werknemer en sy gesin, as vir die organisasie.

Werkgewers moet hul organisasie waardes en operasionele praktyke gereeld evalueer ten einde te verseker dat 'n kultuur ontwikkel word wat werknemerwelstand bevorder. Csiernik (2005:216-217) meld dan ook dat 'n organisasie se beleid die werknemer se welstand behoort te bevorder en sodoende werknemers in staat stel om 'n positiewe bydrae tot die werk, hul gesin en die gemeenskap te maak. Kenny (2000:380) meld dat 'n algemene sienswyse bestaan dat die probleem van stres in die individu gesetel is en dat hy self die verantwoordelikheid moet neem om verandering te bewerkstellig. Bohle (1993:111) merk dan ook tereg op dat “...since no attempt is made to reduce or remove environmental stressors, interventions can best be seen as attempts to increase workers' tolerance of noxious and stressful organisational, task and role characteristics".

Werkgewers het derhalwe 'n verantwoordelikheid om 'n gunstige en ondersteunende organisasieklimaat vir die werknemers te vestig. Kenny (2000:384) meld dat 'n gunstige en ondersteunende organisasieklimaat werknemers in staat stel om meer geredelik by die operasionele werkseise aan te pas, eerder as om verandering op die werk per se te rig. Navorsing dui daarop dat stresverwante probleme meer kompleks is as enige ander fisiologiese siektetoestand. Aangesien die werknemer meeste van sy tyd aan werk en die gesin bestee is dit noodsaaklik dat beide die individu en die organisasie insette moet lewer ten einde die werknemer se funksionaliteit te herstel. 
Stres, as negatiewe toestand en ervaring, is vir die individu 'n oorsaak van vele negatiewe emosies en gesondheidstoestande. Grimshaw (1999:284) meld dat dit noodsaaklik is om stres binne die werkkonteks aan te spreek deur nie slegs op die verandering van die individu te fokus nie, maar ook op die verandering van die werknemer se verhouding met die organisasie en verandering van aspekte van die organisasie self. Grimshaw (1999:389) verwys na negatiewe uitkomste vir die werknemer as uitbranding en werkontevredenheid. Afwesigheid, hoë personeelomset en lae produktiwiteit word as negatiewe uitkomste vir die organisasie voorgehou.

Die organisasie behoort dus daarna te streef om 'n gesonde organisasiekultuur te ontwikkel en te behou ten einde sodanige organisasiekultuur as teenvoeter vir die ontwikkeling van stres en die nadelige invloed daarvan op die gehalte van werklewe te beperk. In aansluiting hierby, behoort elke organisasie ook daarna te streef om strategieë te ontwikkel en toe te pas ten einde welstand en gehalte van werklewe te bevorder.

\section{SAMEVATTING}

Vanuit die literatuur blyk dit duidelik dat verandering in die werksomgewing en die gevolglike stres wat dit meebring, op die werknemer se belewenis van welstand en gehalte van werklewe impakteer (Bishop, 1998:183; Heaney, 2003:306). Organisasies neig om meer tyd in die onderhoud van hul tegnologiese toerusting spandeer in teenstelling met die insette wat hul lewer om hul werknemers gelukkig en gesond te hou. Daarom dan dat dit noodsaaklik is dat organisasies verantwoordelikheid moet neem om 'n gesonde werksomgewing te vestig sodat stressore verminder, gehalte van werklewe verkry en werknemerwelstand bevorder kan word.

Die resultate wat tydens hierdie navorsing na vore gekom het, het sowel die drastiese veranderinge wat die Suid-Afrikaanse tersiêre opleidingsinstellings ondergaan het as die impak daarvan op die stresvlakke van werknemers, bevestig. Die rasionaal vir die ondersoek na die effek van stres in die betrokke tersiêre opleidingsinstelling was om te bepaal in watter mate die veranderinge 'n negatiewe impak op die werknemers se belewenis van die gehalte van werklewe het. Daar is bevind dat die veranderinge wat die Suid-Afrikaanse tersiêre opleidingsinstellings ondergaan het, wel die werknemers se gehalte van werklewe negatief beinvloed het. Hierdie studie het verder bevind dat stres wel aanwesig is en dat stres 'n wesenlike impak op die GWL van werknemers van die betrokke tersiêre opleidingsinstelling het.

\section{ALGEMENE AANBEVELINGS}

Gegewe die rol van universiteite in die sosiale- en ekonomiese welstand van Suid-Afrika, is dit noodsaaklik dat 'n omvattende studie van werkstres soos deur akademici aan Suid-Afrikaanse universiteite ondervind, onderneem word.

Die impak van trauma binne en buite die werkplek op werknemers van tersiêre opleidingsinstellings se stresvlakke behoort ondersoek te word.

Sowel bestuur as werknemers behoort deur bewusmakingsveldtogte, soos byvoorbeeld tydens gesondheidsdae, ingelig en opgelei te word oor die impak van stres op die gehalte van werklewe - voortspruitend uit die voortdurend veranderende werksomgewing en die impak daarvan op werknemers: 


\section{BIBLIOGRAFIE}

ANDERSON, J.E., GUIDO-DIBRITTO, F. \& MORRELL, J.S. 2000. Factors that influence satisfaction for student affairs administrators. In: HAGEDOM, L.S. What contributes to job satisfaction among faculty and staff. San Francisco: Jossey-Bass Publishers.

ATKINSON, W. 2000. Strategies for workplace stress. Risk \& Insurance, 15 Oct 2000. Beskikbaar: http://findarticles.com/p/articles/mi_m0BJK/is_13_11/ai_66930268. [Toegang verkry: 04/07/2005].

AUSTRALIAN BUREAU OF STATISTICS, 2001. Measuring wellbeing: framework for Australian structures. Canberra, ABS Cat. No. 4160.0 - 2001/10/12.

BABBIE, E. 2007. The practice of social research $\left(11^{\text {th }}\right.$ ed). California: Thomson Wadsworth Inc.

BABBIE, E. \& MOUTON, J. 2006. The practice of social research. Cape Town: Oxford University Press.

BARLING, J. 1995. Work and family: in search of the missing links. Employee Counselling Today, 7(7):18-27.

BASSON, C. 1992. Occupational stress. PSA. February: 22-24.

BEALE, A. 2003. Dealing with stress in the British Fire Service. Fire, Jan 2003. Beskikbaar: http://www.findarticles.com [Toegang verkry: 04/07/2005].

BISHOP, F.M. 1998. Wellness in the workplace: a fourfold path. In: KLARREICH, S. Handbook of organizational health psychology. Programs to make the workplace healthier. Connecticut: Psychosocial Press.

BOHLE, P. 1993. Work psychology and the management of occupational health and safety: an historical overview. In: QUINLAN, M. (ed) Work and health: the origins, management and regulation of occupational illness. Melbourne: MacMillan Education.

BRUN, J.-P. \& LAMARCHE, C. 2006. Assessing the costs of work stress. Research Report, 1/2006. University Laval, Quebec, Canada.

BURUD, S.L. \& TUMULO, M. 2004. Leveraging the new human capital: adaptive strategies, results achieved, and stories of transformation. California: Davies-Black Publishers.

BUYS, R. 2008. Die invloed van stres op die gehalte van werklewe en die effektiwiteit van 'n "stresbeheerprogram" aan 'n tersiêre opleidingsinstelling. Pretoria: Universiteit van Pretoria (DPhil Proefskrif)

CALITZ, F.J.W. \& WEYERS, C.F. 1998. Stress and anxiety management training. CME, 16(1):33-37.

CARTWRIGHT, S. \& COOPER, C.L. 1997. Managing workplace stress. Thousand Oaks: Sage Publications.

CARTWRIGHT, S. \& COOPER, C.L. 2004. ASSET: Management Guide. Manchester: Robertson Cooper Ltd.

CASCIO, W.F. 2003. Managing human resources. Productivity, quality of work life, profits $\left(6^{\text {th }}\right.$ ed). New York: McGraw-Hill.

CLAASSEN, L., SCHEPERS, J. \& ROODT, G. 2004. Werkswaardes van akademici. Tydskrif vir Bedryfsielkunde, 30(4):82-92. 
CLARKE, S.G. \& COOPER, C.L. 2000. The risk management of occupational stress. Health, Risk and Society, 2(2):173-187.

CLARKE, S.G. \& COOPER, C.L. 2004. Managing the risk of workplace stress. London: Routledge.

COETZEE, S.E. \& ROTHMAN, S. 2005. Occupational stress, organisational commitment and ill-health of employees at a higher education institute. SA Journal of Industrial Psychology, 31(1):47-54.

COOPER, C.L. 2000. Theories of organisational stress. Manchester: Oxford University Press.

CRANWELL-WARD, J. \& ABBEY, A. 2005. Organizational stress. New York, Palgrave: MacMillan.

CSIERNIK, R. 2005. Wellness and work. Employee Assistance programming in Canada. Toronto: Canadian Scholars' Press.

CUMMINGS, P.C. 2000. EAPs, another service in today's stressful workplace. San Diego Business Journal, 21(3):58.

DAVIES, P.T. \& CICCHETTI, D. 2004. Toward an integration of family systems and developmental psychopathology approaches. Development and Psychopathology, 16:477481.

DOLLARD, M.F. 2003. Context, theories and intervention. In: DOLLARD, M.F., WINEFIELD, A.H. \& WINEFIELD, H.R. Occupational stress in the service professions. London: Taylor \& Francis.

DOLLARD, M.F., WINEFIELD, A.H. \& WINEFIELD, H.R. 2003. Occupational stress in the service professions. London: Taylor \& Francis.

EDWARD, J.R., CAPLAN, R.D. \& VAN HARRISON, R. 2000. Person-environment fit theory: conceptual foundation, empirical evidence, and directions for future research. In: COOPER, C.L. Theories of organisational stress. Manchester: Oxford University Press.

FRONE, M.R. 2003. Work-family balance. In: QUICK, J.C. \& TETRICK, L.E. (eds) Handbook of occupational health psychology. Washington, DC: American Psychological Association.

GALINSKY, E., BOND, J.T. \& FRIEDMAN, D.E. 1996. The role of employers in addressing the needs of employed parents. Journal of Social Issues, 52(3):111-136.

GILlESPIE, N.A., WALSH, M., WINEFIELD, A.H., DUA, J. \& STOUGH, C. 2001. Occupational stress in universities: staff perceptions of the causes, consequences and moderators of stress. Work \& Stress, 15(1):53-72.

GRATTON, L. 2003. Putting people at the heart of strategy. Management Today, 19(4):4-6.

GREEN, F.B. \& HATCH, E. 2002. Does business process re-engineering diminish the quality of worklife? Social Indicators Research, 60:299-307.

GRIMSHAW, J. 1999. Employment and health: psychosocial stress in the workplace. London: The British Library.

HAGEDORN, L.S. 2000. What contributes to job satisfaction among faculty and staff. San Francisco: Jossey-Bass Publishers. 
HAY, D. \& FOURIE, M. 2002. Preparing the way for mergers in South Africa higher and further education institutions: An investigation into staff perceptions. Higher Education, 44(1):115-131.

HEANEY, C.A. 2003. Worksite-health interventions: targets for change and strategies for attaining them. In: QUICK, J.C. \& TETRICK, L.E. (eds) Handbook of occupational health psychology. Washington, DC: American Psychological Association.

HOEL, H., SPARKS, K. \& COOPER, C.L. 2005. The cost of violence/stress at work and the benefits of a violence/stress-free working environment. Report commissioned by the international labour organization (ilo) Geneva. University of Manchester, UK.

HUGHES, S. 2004. The stress response. Manchester: Machester Institute of Psychotherapy.

IRMSA. 2005. IRMSA (Institute of Risk Management South Africa). Available: http://www.irmsa.co.za. [Accessed: 11/05/2006].

JAMES, K. \& ARROBA, T. 1999. Energizing the workplace: a strategic response to stress. England: Gower Publishing.

JANSEN, J.D. 2002. Mergers in higher education: lessons learned in transitional contexts. Pretoria: Unisa Press.

KENNY, D.T. 2000. Occupational stress: reflections on theory and practice. In: KENNY, D.T., CARLSON, J.G., McGUIGAN, F.J. \& SHEPPARD, J.L. Stress and health: research and clinical applications. Australia: Harwood Academic Publishers.

KENNY, D.T., CARLSON, J.G., McGUIGAN, F.J. \& SHEPPARD, J.L. 2000. Stress and health: research and clinical applications. Australia: Harwood Academic Publishers.

KLARREICH, S. 1998. Handbook of organizational health psychology. Programs to make the workplace healthier. Connecticut: Psychosocial Press.

LEKA, S., GRIFFITHS, A. \& COX, T. 2003. Work organization and stress. Switzerland: WHO.

LEVI, L. 2000. Stress management and prevention on a European community level: options and abstacles. In: KENNY, D.T., CARLSON, J.G., McGUIGAN, F.J. \& SHEPPARD, J.L. Stress and health: research and clinical applications. Australia: Harwood Academic Publishers.

LU, L., WU, H. \& COOPER, C.L. 1999. Perceived work stress and locus of control: a combined quantitative and qualitative approach. Research and Practice in Human Resource Management, 7(1):1-15.

MAPESELA, M.L.E. 2004. Academic staff satisfaction suffers due to increased learner access and redress. SA Journal of Higher Education, 18(2):265-277.

MARTEL, J. 2005. The sources of workplace stress. University Laval, Quebec, Canada.

McGOWAN, J., GARDNER, D. \& FLETCHER, R. 2006. Positive and negative outcomes of occupational stress. New Zealand Journal of Psychology, July.

METCALF, H.; ROLFE, H.; STEVENS, P. \& WEALE, M. 2005. Recruitment and retention of academic staff in higher education. London: National Institute of Economic and Social Research. Research Report RR658.

MEYER, D. 2007. HIV/AIDS in Africa and its impact on education. Science Education \& Civic Engagement, (1):4-22. 
MILLER, L.H. \& SMITH, A.D. 2004. The different kinds of stress. Washington: American Psychological Association.

NELSON, D.L. \& SIMMONS, B.L. 2003. Health psychology and work stress: a more positive approach. In: QUICK, J.C. \& TETRICK, L.E. (eds) Handbook of occupational health psychology. Washington, DC: American Psychological Association.

NEUMAN, W.L. 1997. Social research methods: qualitative and quantitative approaches. Boston: Allyn \& Bacon.

PAULSE, J. 2005. Sources of occupational stress for teachers, with specific reference to the inclusive education model in the Western Cape. Cape Town: University of the Western Cape. (MA Dissertation)

PHILLIPS, L.J. 2005. A prospective study of the relationship between stress, coping and the onset of psychosis in a high risk group. Australia: The University of Melbourne. (DPhil Thesis)

PUTT, V. 2006. Stress in a nutshell. Winchester: Winchester City Council.

QUICK, J.C. \& TETRICK, L.E. (eds) 2003. Handbook of occupational health psychology. Washington, DC: American Psychological Association.

QUINLAN, M. (ed) 1993. Work and health: the origins, management and regulation of occupational illness. Melbourne: MacMillan Education.

REQUENA, F. 2003. Social capital, satisfaction and quality of life in the workplace. Social Indicators Research, 61:331-360.

ROMAS, J.A. \& SHARMA, M. 2000. Practical stress management. A comprehensive workbook for managing change and promoting health $\left(2^{\text {nd }}\right.$ ed). Boston: Allyn \& Bacon.

SCHAFER, W. 2000. Stress management for wellness $\left(4^{\text {th }}\right.$ ed $)$. New York: Harcourt College Publishers.

SEGUMPAN, R.G. \& BAHARI, F.B. 2006. Teachers' job stress and human resource development: the Malaysian experience. In: LAMBERT, R.G. \& McCARTHY, C.J. Understanding teacher stress in an age of accountability. Charlotte: Information Age Publishing.

SITHOLE, S.L. 2002. A needs assessment and implementation guidelines for an EAP at the University of the North. Pretoria: University of Pretoria. (DPhil Thesis)

STEENKAMP, R. \& VAN SCHOOR, A. 2002. The quest for quality of worklife - a TQM approach. Cape Town: Juta.

TANGRI, R. 2003. Stress-costs. Stress-cures. Canada: Ravi Tangri.

ULLYAT, T. 2003. The four-year eternity: sacrifice, death and resurrection as metaphors for aspects of tertiary institutional transformation. SAJHE/SATHO, 17(1):83-90.

VAN KLAVEREN, M. \& TIJDENS, K. 2007. Work-related stress. WIBAR Report, No. 6. Nederland: Wageindicator Bargaining.

VERESPEJ, M.A. 2000. Stressed out: increasing stress levels among employees. Industry Week, 21:1-10.

VROOM, V.H. 1964. Work and motivation. New York: Wiley. 
WINEFIELD, A.H. 2003. Stress in university academics. In: DOLLARD, M.F., WINEFIELD, A.H. \& WINEFIELD, H.R. Occupational stress in the service professions. London: Taylor \& Francis.

WORLD HEALTH ORGANIZATION (WHO). 1948. Preamble to the Constitution of the World Health Organization as adopted by the International Health Conference, New York, 1922 June, 1946; signed on 22 July 1946 by the representatives of 61 States (Official Records of the World Health Organization, no. 2, p. 100) and entered into force on 7 April 1948.

Dr Rina Buys, Prof Lourie Terblanche, Departement Maatskaplike Werk en Kriminologie, Universiteit van Pretoria, Pretoria, Suid-Afrika. 